\title{
Impregnated Pad Dosage Form
}

National Cancer Institute

\section{Source}

National Cancer Institute. Impregnated Pad Dosage Form. NCI Thesaurus. Code C149571.

Solid preparation consisting of a piece of absorbent material impregnated with a liquid preparation. 